\title{
Correlations between Online Learning Media Types, First Access Time, Access Frequency, and Students' Achievement in a Flipped Classroom Implementation
}

\author{
Daniel Febrian Sengkey * \\ Electrical Engineering Department, \\ Faculty of Engineering, \\ Universitas Sam Ratulangi \\ Manado, 95115, Indonesia \\ danielsengkey@unsrat.ac.id
}

\author{
Sary Diane Ekawati Paturusi \\ Electrical Engineering Department, \\ Faculty of Engineering, \\ Universitas Sam Ratulangi \\ Manado, 95115, Indonesia \\ sarypaturusi@unsrat.ac.id
}

\author{
Alwin Melkie Sambul \\ Electrical Engineering Department, \\ Faculty of Engineering, \\ Universitas Sam Ratulangi \\ Manado, 95115, Indonesia \\ asambul@unsrat.ac.id
}

\begin{abstract}
Since the 1960s, the world has seen how information technology (IT) influences education. In the present era, with the massive development of the Internet, various kinds of IT-assisted learning are popping up like mushrooms in the rainy season. However, no matter how advanced IT-assisted learning has been grown, learning media is still an inseparable part of education. Former studies already covered students' preferences toward various types of media, yet none discussed the achievements. In this study, we specifically present how the use of certain types of learning media correlated with students' access behaviors and, more importantly, students' achievement. The data were collected from the Learning Management System (LMS) activity logs of 44 students from the undergraduate program in Informatics, with former experience of using e-learning. The result shows that these factors have a positive correlation. In terms of media type influence towards students' achievement, the media that has the appearance of the lecturer gives better achievement, compared to the media that only has audio, and the media that only consists of text and images.
\end{abstract}

Keywords: blended learning, flipped classroom, learning media, students' access behaviors, students' achievement.

\footnotetext{
${ }^{*}$ Corresponding Author with contact details email address and full postal address
} 


\section{Introduction}

Since the decade of the 1960s, the world has been presented with various types of Information Technology (IT) assisted learning (Aparicio et al. 2016). The scenario span from computer-assisted, up to the contents that available for massive access via the Internet. The IT adoption in the education realm has triggered learning with the help of electronic means, which known as e-Learning, such as the use of compact disc with educational contents; classrooms with geographically separated participants (distance learning); and online learning, where the contents are stored in a server which is accessible from the Internet (Moore et al. 2011). The adoption of technology is considered beneficial due to the nature of the present target audiences from the learning contents, which are the millennials, where most of them are digital natives (Okaz 2015). According to an evaluation by Hubackova and Semradova (2016), blended learning is a favored learning style for students.

To deliver the topics to the learners, the use of suitable media can be considered as an inseparable thing from learning. Despite the abundance of resources available online, the main source of information and guidance is still one provided by the lecturer (Gutmann et al. 2015). However, when discussing media, one could not deviate away from communication science. It is found that video-based communication imitates the bonding of in-person communication better than text-based communication (Sherman et al. 2013). On the other hand, in a business-communication study, it is found that the use of multimedia advertising is beneficial to the corporation. Therefore, as also found by Putri and Solfema (2019), the use of various types of learning media affects learning activities positively.

In 2018, a study about student's preference toward learning media in a flipped classroom blended learning setup was conducted by Gozali et al. (2018). The study compared three types of learning media: the first one came in the form of webpages with text-and-images, and the second type was recorded slide show with audio narration from the lecturer; the last media type studied was recorded slide show, now with the lecturer actively explaining the lecture materials. The findings show a relatively similar preference for all three, with a slight difference in achievement. An extended study, with a focus on the access styles, was reported by Sengkey, Paturusi, et al. (2019). The term "access styles" is referring to did the student access to the media? Did one make repetitive access or only once? Was there any part skipped? It was found that the students tend to access the third type of learning media repeatedly. The same authors also reported another study, where they asked the students to assess the same media types. The study reported that the slide-based media commonly have higher scores compared to ones with only text-and-images (Sengkey, Sambul, et al. 2019).

Even though the media comparisons seem already studied thoroughly, there niches and gaps that are not filled yet, and questions that still need an answer. The previous studies already made comparisons between these media, yet they have not addressed the results achieved by students. On the other hand, how strong the correlation between media types, access frequency, the first access made by students, and the students' achievements are not found in those studies. Therefore, in this study, we try to answer how these things are inter-correlated one and another. The next sections are organized as follows: Literature Review presents the state-of-the-art of this study, next in Methodology,Error! Reference source not found. we present the detailed information regarding how the study took place; next in Results and Discussion we present the findings as well as results of statistical comparisons between the parameters under study. Last, in Conclusion, this paper is concluded.

\section{Literature Review}

\section{Learning Media}

The word "media", which is the plural form of "medium" (Lister et al. 2009). Medium means an intermediary or a mean, which is used to convey something. As described earlier, in a study about the implementation of rich media (multimedia) in a commercial web, it is found that the use of such media yields higher trust from the visitor (Appiah 2006). Respondents in research about communication means (Sherman et al. 2013), testified that video chats have a higher impact on their bonding, and compared with audio chat and text-based chat (instant messaging). 
In education, learning media is a means to convey messages, which are the educational contents or learning materials, where the goal is the learning process to happen (Nurseto 2012; Susilana and Riyana 2009). According to Kosasih and Angkowo (2007), optimal learning media will stimulate students to learn. In a study of the participants of the Paket $B$ program, the variation in learning media used may lead to the more active involvement of the students (Putri and Solfema 2019). To the extent of an interesting learning media, the systematic planning of the learning media use must implement the VISUALS (Visible, Interesting, Simple, Useful, Accurate, Legitimate, Structured).

With the development of IT, then come a higher chance of developing more varying and interesting learning media. Within the last decade, multimedia-based learning media have become something that is commonly developed and adopted. The experience of Hadibin et al. (2013) in implementing interactive multimedia-based learning media for a vocational high school proves that the use of such media increases the learning interest of the students so that they were not easily getting bored. On the other hand, from the perspective of the educator, the availability of the media is considered helpful. In another study, where the researchers used Adobe Flash to develop an interactive learning media, the findings are also positive, as indicated by the students' ability to think more critically (Gayatri et al. 2018).

\section{IT-Assisted Learning}

IT-assisted learning has been existing since the 1960s, started with Computer Assisted Instruction (CAI) until the present development such as Massive Open Online Course (MOOC), Small Private Online Course (SPOC), Little Open Online Course (LOOC), and Distributed Open Collaborative Course (DOCC) (Aparicio et al. 2016). Even only from the terminologies, it can be inferred that the utilization of computers and the Internet to support learnings are coming to a point where the learning path becomes adaptive (self-paced), open online, distributed, and collaborative. According to a study that involved Indonesian and Mongolian higher education institutions, IT-assisted learning has a huge potential, especially when implemented in undergraduate and postgraduate course-based programs (Usagawa and Ogata 2015). Now, with the availability of the Learning Management System (LMS), such as MOODLE (Dougiamas and Taylor 2003), the technical obstacle in implementing this type of learning is reduced. Even with the availability of the well-known LMS MOODLE, still, some studies try to develop LMS by using PHP frameworks, such as CodeIgniter, as reported by Putri (2018). These potentials are proofed to a very beneficial during a global pandemic. For example, Sengkey et al. (2020) utilized mixed platforms, LMS and Google Colab to deliver an activity-based of Probability and Statistics course during Study from Home (SFH) time. However, the implementation itself is not free from challenges. A literature study by Aini et al. (2020) found that either students and instructors have barriers to develop and access an online course, especially in terms of connectivity and ICT skills.

The evaluation of a blended-learning course that was designed with instructional model Analysis, Design, Development, Implementation, and Evaluation (ADDIE), that was implemented in a public university in Indonesia shows a positive impact on learning motivation and achievement, due to the possibility of self-paced learning (Paturusi et al. 2012). The extent of the study found that blendedlearning brought enhancements to students' performance and learning achievements, and on the other hand, the students had more satisfaction with it (Paturusi et al. 2016). In another study by Setyaningrum (2018), blended learning helps students to have deeper conceptual knowledge, due to the possibility to access the learning contents repeatedly, especially ones that presumably difficult. The same author also studied the educator's perspective on blended learning implementation. The result shows that the educators, especially ones that younger and/or hold a higher degree, have a positive perception toward it (Setyaningrum 2016). A study on the user acceptance of e-Learning suggests that the e-Learning characteristics as a major factor that influences adoption by the lecturer (Suarta and Suwintana 2015).

Learning media cannot be separated from the learning process itself, even so in IT-assisted learning environments. Technological advancements had made learning media in digital format available as demonstrated in previous studies (Gayatri et al. 2018; Hadibin et al. 2013). A study by Abuloum et al. (Abuloum et al. 2019) even found that the students have a higher preference for digital textbooks than the conventional ones. It is even better for students with prior engagement to online learning, due to the higher level of motivation in online courses (Wang et al. 2013). In regards to performance, the findings 
of Hart et al. (2019) shows that students tend to perform better in online courses. Aligned with Wang et al. (2013), Hart et al. (2019) also found that prior experience is a benefit.

Former studies, (Gozali et al. 2018; Sengkey, Paturusi, Sambul, et al. 2019; Sengkey, Sambul, et al. 2019) were done by using questionnaires to collect responses from students. Another work by the same authors made use of the activity log available from the LMS to evaluate pre-classroom students' behavior, in terms of media access, in the same class setup as the earlier papers. The study concluded that the students mostly access the text-and-images first rather than the other two (Sengkey, Paturusi, and Sambul 2019). In a later study, where the authors involved more students and courses, they found that text-and-images media were the most frequently accessed yet the slide show with recorded narration mostly gained the earliest accesses with statistically significant differences than the other two (Sengkey, Paturusi, et al. 2020).

\section{Methodology}

\section{Locus and Respondents}

The research reported in this article adopted the same method as used by studies in this particular field (Gozali et al. 2018; Sengkey, Paturusi, and Sambul 2019; Sengkey, Paturusi, et al. 2020; Sengkey, Paturusi, Sambul, et al. 2019; Sengkey, Sambul, et al. 2019). Moreover, parts of the data discussed in this article were discussed in the last study (Sengkey, Paturusi, et al. 2020). The data came from a course with code IFN304, Network Communications that was held in the fall semester of 2019. This is a 5 credits course, held in the $3^{\text {rd }}$ semester on the Undergraduate Program in Informatics, Universitas Sam Ratulangi. Due to its credit, then this course is scheduled twice a week, on Tuesday and Thursday. There were 44 students enrolled in this course when the data were taken. These students have former experience with e-learning environments and the LMS used in this research. Besides that, since they are IT students, they are also considered to possess the skills required to use e-learning fluently.

\section{Media Types and Codes}

As described earlier, there were 3 types of media used, as adapted from the previous studies (Gozali et al. 2018; Sengkey, Paturusi, and Sambul 2019; Sengkey, Paturusi, et al. 2020; Sengkey, Paturusi, Sambul, et al. 2019; Sengkey, Sambul, et al. 2019). Therefore, we also adopted the same codes/abbreviations, which are: TIM for learning media that consists of text-and-images only; SAD for a recorded slideshow with the audio narration from the lecturer, explaining the contents; and VID, which is similar to $\mathrm{SAD}$, but this one with the lecturer appear in-frame, explaining the contents.

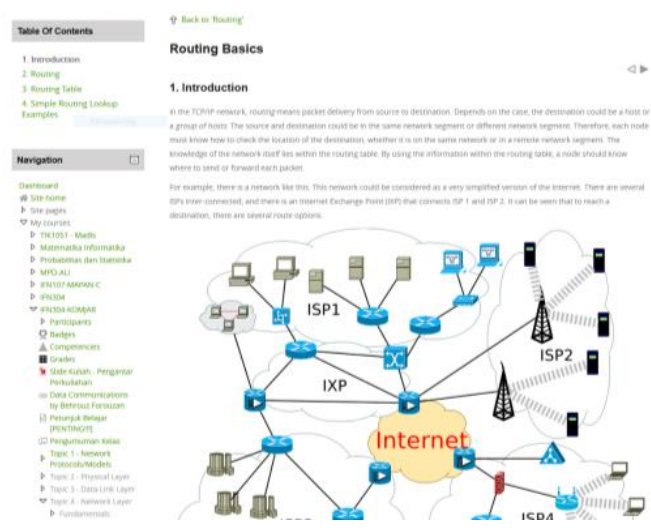

Figure 1. An example of text-and-image (TIM) learning media, as shown in the LMS. 
Figure 2. An example of the recorded slide with audio narration (SAD) learning media, as embedded into the LMS.

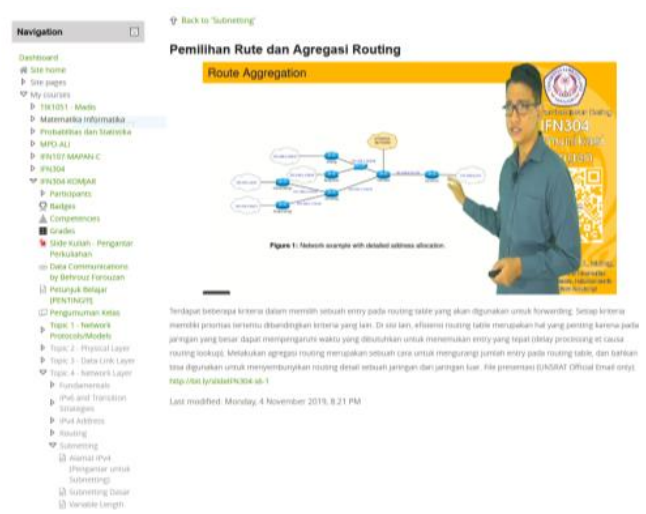

Figure 3. An example of the learning media of the recorded slide that has the lecturer appears inside the frame (VID). As can be seen, it is embedded into the LMS.

TIM media came in the form of webpages, accessible from the LMS. Since video-based media are taking a lot of space, the SAD and VID media were uploaded to a third-party video sharing site and then embedded inside the LMS. The examples of TIM, SAD, and VID are shown in Figure 1, Figure 2, and Figure 3, respectively.

\section{Lectures, Sessions, and Media}

To achieve justifiable results, and avoid bias, the study was applied to six lecture sessions, wherein each session all media types were used in a different order. It means, in each session, the topic was brokedown into three parts (modules), where each part will be exclusively delivered by using one of the media studied. Another measure that was taken to avoid student's bias, is randomizing the permutation of the media sequence for each session. We even went further by using a script in $\mathrm{R}$ language to free the randomization from human intervention. The schedule is shown in Table 1.

\section{Parameters, Boundaries, and Data Sources}

As described earlier, four parameters studied in this research: 1). media types; 2). access frequency; 3 ). the number of hours the first access was made toward a particular learning media, relative to the scheduled lecture; 4). Students' achievements. The media were provided by the lectures and made available in the LMS. The access frequency and the time of the first access are obtained from the activity $\log$, available from the LMS. This log contains all activities made by all participants, lecturers, students, or even guests, including the timestamp for each activity. Therefore, several additional steps were done to clean this dataset from unneeded data, and transform it into a tidied format. The cleaning steps are 
filtering out activities that were not done by students, transforming the timestamps to "\%d/\%m/\%y $\% \mathrm{H}: \% \mathrm{M} "$ format, and then extracting the log lines for each module. After that, in each module, the difference between the scheduled lecture and the first access made by each student was extracted by subtracting the former with the later numbers.

Table 1. The lecture sessions, modules, and media type used for each sub-topic

\begin{tabular}{|c|c|c|c|c|c|c|c|c|c|}
\hline \multirow{2}{*}{$\begin{array}{c}\text { Session } \\
\text { (Lectures) }\end{array}$} & \multirow{2}{*}{ Modules } & \multicolumn{3}{|c|}{ Media Types } & \multirow{2}{*}{$\begin{array}{c}\text { Session } \\
\text { (Lectures) }\end{array}$} & \multirow{2}{*}{ Modules } & \multicolumn{3}{|c|}{ Media Types } \\
\hline & & TIM & SAD & VID & & & TIM & SAD & VID \\
\hline \multirow{3}{*}{1} & 1.1 & & & & \multirow{3}{*}{4} & 4.1 & & & \\
\hline & 1.2 & & & & & 4.2 & & & \\
\hline & 1.3 & & & & & 4.3 & & & \\
\hline \multirow{3}{*}{2} & 2.1 & & & & \multirow{3}{*}{5} & 5.1 & & & \\
\hline & 2.2 & & & & & 5.2 & & & \\
\hline & 2.3 & & & & & 5.3 & & & \\
\hline \multirow{3}{*}{3} & 3.1 & & & & \multirow{3}{*}{6} & 6.1 & & & \\
\hline & 3.2 & & & & & 6.2 & & & \\
\hline & 3.3 & & & & & 6.3 & & & \\
\hline
\end{tabular}

To obtain the students' achievements, for each lecture there was an offline test held in the class as shown in Figure 4, during the first 30 minutes of the lecture. Each test had 15 multiple-choice questions, five for each module (that was delivered by a certain media). The questions were designed at $\mathrm{C} 1$ or $\mathrm{C} 2$ levels of Bloom Taxonomy. Later, the number of correct answers or later known as scores were tabulated and merged with the tidied log, into a table as shown in Figure 5.

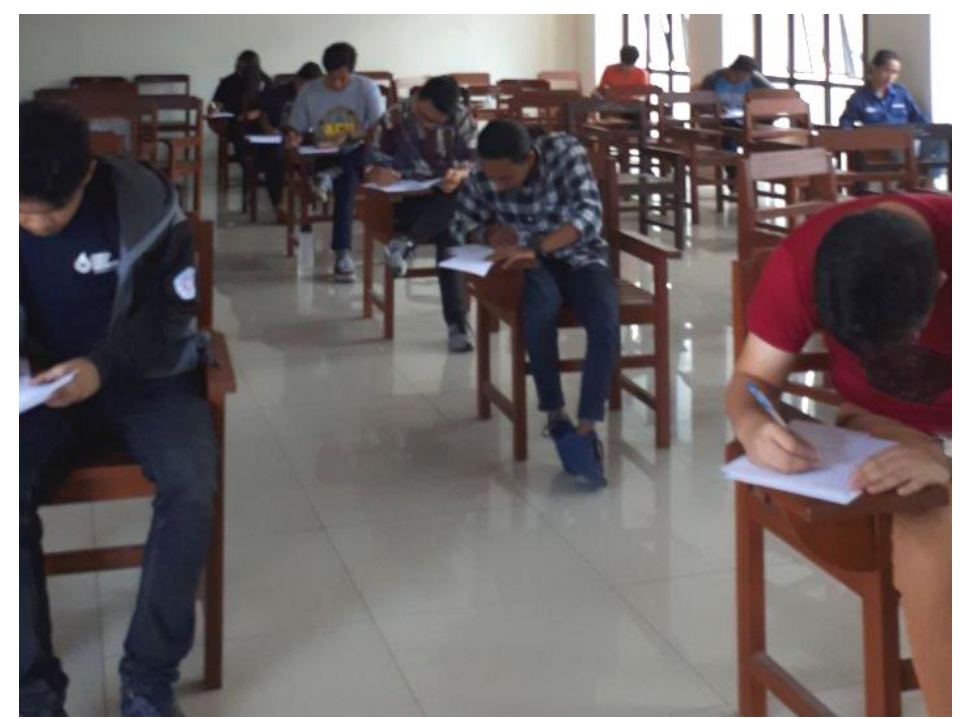

Figure 4. Students working on the test in one of the scheduled lectures. 


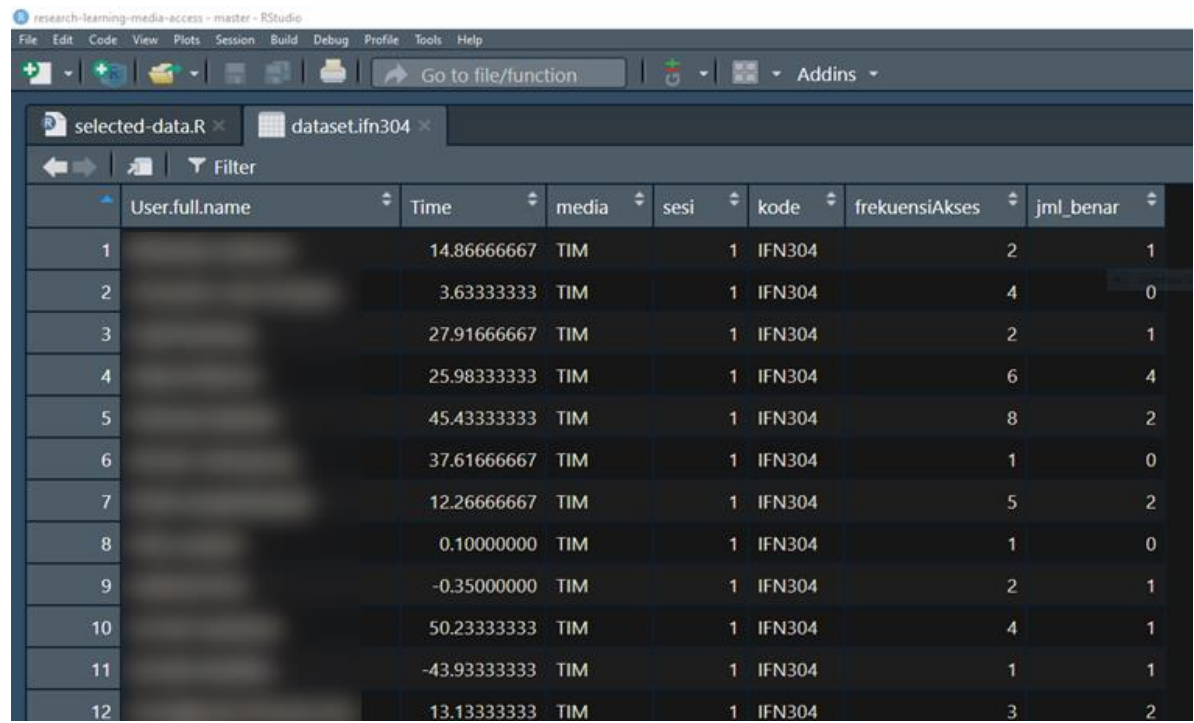

Figure 5. Screenshot of tidied data synthesized from the course log and the number of correct answers for the respective session and media, shown in the RStudio window.

As previously done by Sengkey et al. (2020), this study also adopts the limitation for the first access time. As this course was scheduled twice a week, hence if a student accessed the media long after the scheduled lecture, it should be considered as an improper act. Therefore, for this study, we limit the first access time to no later than 72 hours (three days) after the scheduled lecture. Late access is still accommodated up to 72 hours due to the consideration of the load from other courses, the possibility of connectivity issues, and some other obstacles that might happen. Regarding the representation of the number, since we concern with the number of hours before the scheduled lecture, then late access (after schedule) is represented with a negative number, and vice versa, the number of hours before the scheduled lecture is represented with a positive number. Later, for all statistical tests, we use $90 \%$ confidence level $(\alpha=0.1)$.

\section{Results and Discussion}

\section{Access Frequency}

Figure 6 shows the boxplots for the access frequency of each media, grouped by scores. One thing that is clearly shown in the distribution of access frequency tends to shift to the right side when the score grows higher. Another thing that visible is the presence of outliers. In some cases at the higher scores, there are outliers at the right side of the boxplots, marking extremely frequent access, compared to the common distribution. The general trend for each score group is similar to one discussed in the previous publication, where TIM came as the significantly most frequently accessed media, while the other two, despite the higher access tendency for SAD, the difference is not significant, compared with VID (Sengkey, Paturusi, et al. 2020). 


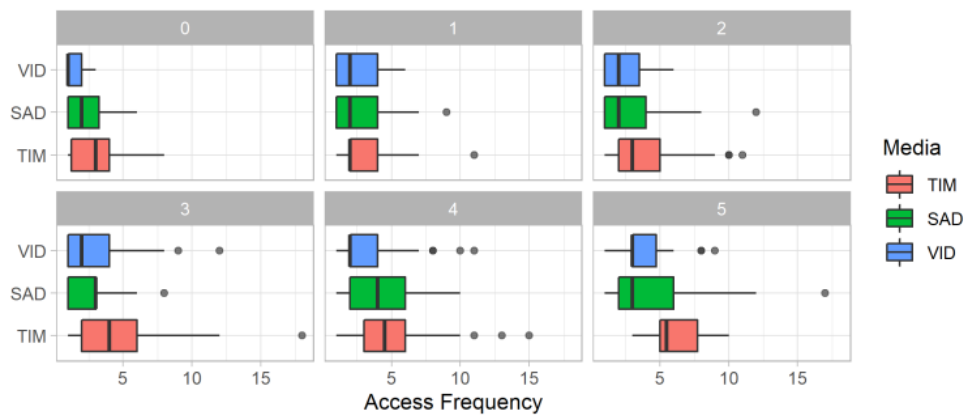

Figure 6. Boxplots of access frequency for each media type, grouped by scores.

\section{First Access Time, Relative to the Scheduled Lecture}

The first access time as subtracted from the scheduled time for a particular lecture, where the respective media are used shows the media that accessed earlier. This parameter, grouped by the score is shown in the boxplots in Figure 7. The trend of early access gained by SAD in each box of the score is also similar to the general comparison done in the previous publication (Sengkey, Paturusi, et al. 2020). The runner-up is TIM, although the difference is not statistically different from VID.

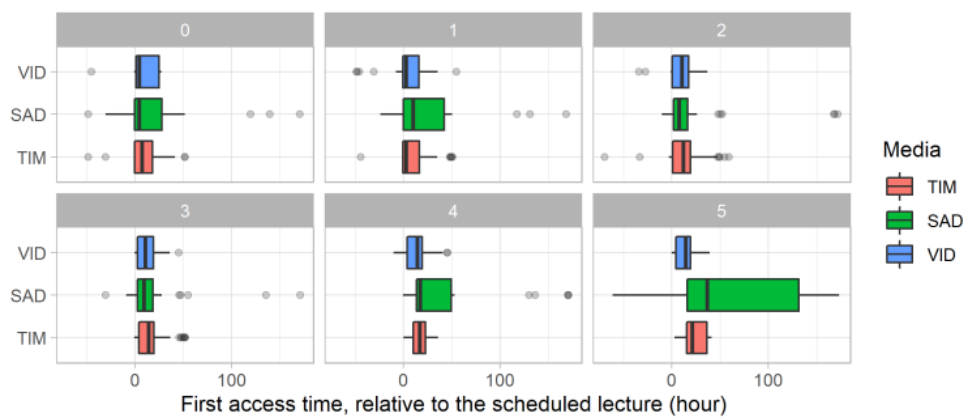

Figure 7. Boxplots of the number of hours the first access was made toward a particular learning media, relative to the scheduled lecture for each media type, grouped by scores.

\section{Correlation}

Even though there were comparisons of some of the parameters discussed in the previous publication (Sengkey, Paturusi, and Sambul 2019; Sengkey, Paturusi, et al. 2020), and the score-grouping done in previous subsections already give some insights about the correlation, however without a proper method of comparison, the inference could not be precise. Hence, to appropriately calculate the correlation between each parameter, a heterogeneous correlation calculation was done by using the polycor software package (Fox 2019), in GNU R version 4.0.2 (R Core Team 2020). In this calculation, the media is assumed as an ordinal variable, where VID is the highest and TIM is the lowest. The correlation is calculated with Maximum-Likelihood Estimates with complete observation, which means all noncomplete observations were not included in the calculation. The results are plotted as a correlogram, as shown in Figure 8. 


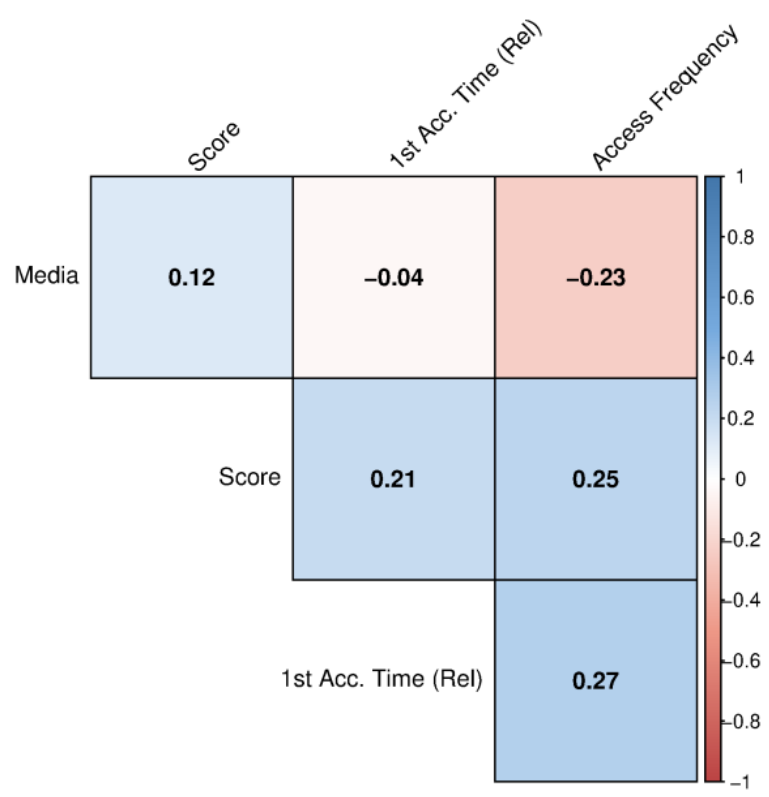

Figure 8. A polychoric correlogram, showing the polychoric correlation coefficients between parameters studied in this research $(n=594)$. The text in each cell is the correlation measure between 2 parameters.

Table 2. Type, Standard errors, and p-value of bivariate normality of the correlation.

\begin{tabular}{|l|r|r|r|r|}
\hline & $\begin{array}{r}\text { 1st Acc. Time } \\
\text { (Rel) }\end{array}$ & Media & \multicolumn{1}{|c|}{$\begin{array}{c}\text { Access } \\
\text { Frequency }\end{array}$} & Score \\
\hline Media & $\begin{array}{r}\text { Polyserial } \\
0.043\end{array}$ & & & \\
& $<0.001^{* * *}$ & & & \\
Access & Pearson & Polyserial & & \\
Frequency & 0.038 & 0.044 & & \\
\hline & $<0.001^{* * *}$ & $<0.001$ & & \\
Score & Pearson & Polyserial & Pearson & \\
& 0.039 & 0.045 & 0.039 & \\
\hline
\end{tabular}

From Figure 8, it can be inferred that generally, the parameters are positively yet weakly correlated, except for Media and the student-access variables where the correlations are negative. It means the complexity of the media used is inversely proportional to the access. Yet in terms of achievement, it shows a slightly positive influence.

The access parameters, whether the earlier the access or the frequency, both show a stronger correlation with the achievement. The directly proportional relation between the earlier access and the frequency is self-explainable. Regarding these access variables and the achievement, the correlations can be inferred as the more time before the lecture gained access toward the media, the higher the achievement. This finding is aligned with the general conclusion from another study that reviewed the effect of time on students' achievement (Yeşil Dağl1 2019). 


\section{Media and Students' Achievement}

Students' achievement is one thing that is commonly used as an indicator of a successful education. Therefore, despite the weak positive correlation between the media types and students' achievement, this subsection provides a further discussion regarding these two parameters. Figure 9 shows boxplots of the number of correct answers (score), which denotes the students' achievement, in each media type. As can be seen, the distribution of the scores in each media types almost similar, especially the medians of the SAD and VID. Yet, these boxplots also show that the score from the SAD media has a higher variance, as can be compared by the length of the boxes.

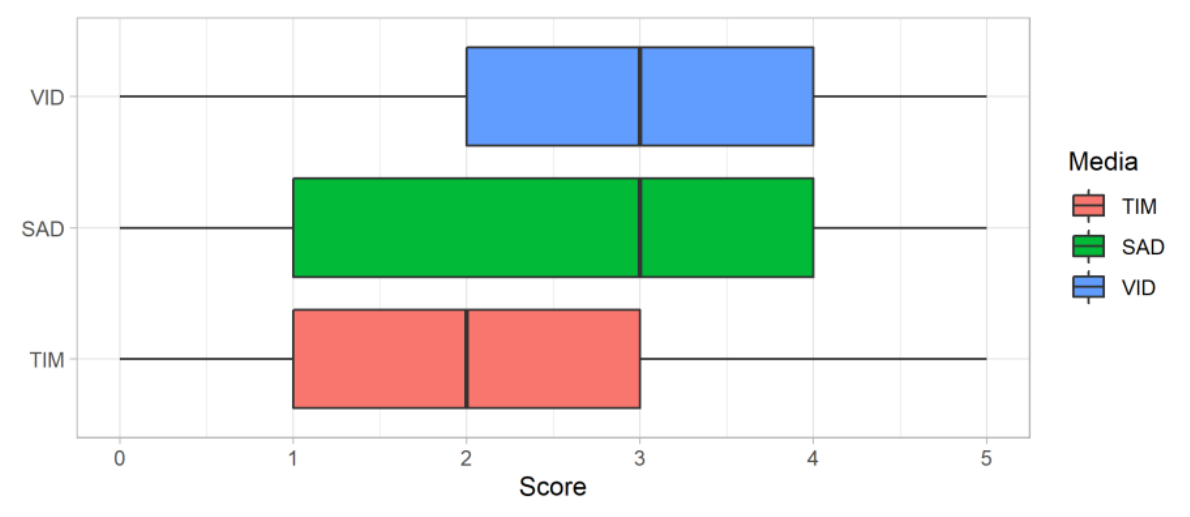

Figure 9. Boxplots of the score (students' achievement) for each type of media.

The statistical summary in Table 3 shows the quantitative trend of what is illustrated in Figure 3. According to these numbers, there is a tendency for better achievement by the VID media, as can be compared from the $\mathrm{Q}_{1}$, mean, and median values. On the other hand, as described earlier, the achievement of SAD is more varied than the other two, as can be seen from the standard deviation.

Table 3. Statistical summary of the score for each media type.

\begin{tabular}{|c|r|r|r|r|r|r|r|}
\hline Media & \multicolumn{1}{|c|}{ Min. } & \multicolumn{1}{c|}{ Q1 } & \multicolumn{1}{c|}{ Mean } & \multicolumn{1}{c|}{ Median } & \multicolumn{1}{c|}{ Q3 } & Max. & Std. Dev. \\
\hline TIM & 0.00 & 1.00 & 2.37 & 2.00 & 3.00 & 5.00 & 1.40 \\
\hline SAD & 0.00 & 1.00 & 2.73 & 3.00 & 4.00 & 5.00 & 1.60 \\
\hline VID & 0.00 & 2.00 & 2.78 & 3.00 & 4.00 & 5.00 & 1.48 \\
\hline
\end{tabular}

We extend the study by applying inference statistics tests to gain a more robust understanding and conclusion toward the phenomenon. Since there are three media types, hence to compare the students' achievements, a multivariate test must be done. Hence, to decide the proper method, we started with the distribution normality test for the scores in each media type. The test used is the Shapiro-Wilk test and the result is presented in Table 4. The null hypothesis for this test is the data is normally distributed, therefore, as can be seen from Table 4, the p-value for each media is far below the defined alpha, and it can be concluded that the data are not normally distributed. Since the data are not normally distributed, further tests must be done with non-parametric methods. For the multivariate test, we used the KruskalWallis test. The result is shown in Table 5. With the p-value equals 0.0155 , then it can be inferred that at least one group has a different distribution, therefore a post-hoc test was carried out by using Dunn's test with Bonferroni adjustment. The result is shown in Table 6. The first line in each cell shows the mean difference between compared groups, which is calculated from the mean of the group in the row subtracted by the mean of the group in the column. This result strengthens the assumption that the use of VID yields better achievement. Based on the p-values, it can be seen that the differences between these three groups are statistically significant at a $90 \%$ confidence interval. The mean differences suggest that VID yields the highest achievement, and TIM is the lowest one. 
Table 4. Results of the Shapiro-Wilk test for distribution normality of score in each media type.

\begin{tabular}{|l|r|r|}
\hline \multicolumn{1}{|c|}{ Media } & $\boldsymbol{W}$ & p-value \\
\hline TIM & 0.936 & $<0.001 * * *$ \\
\hline SAD & 0.917 & $<0.001 * * *$ \\
\hline VID & 0.928 & $<0.001 * * *$ \\
\hline
\end{tabular}

Table 5. Result of the Kruskal-Wallis test on the score.

\begin{tabular}{|l|r|r|c|}
\hline Variable & \multicolumn{1}{|c|}{$\boldsymbol{H}$} & Degree of Freedom & p-value \\
\hline Score & 8.34 & 2 & $0.0155^{*}$ \\
\hline
\end{tabular}

Table 6. Results of the post-hoc test using Dunn's method with Bonferroni adjustment for the score comparison between each media type.

\begin{tabular}{|l|r|r|}
\hline $\begin{array}{l}\text { Row Mean-Col Mean/ } \\
\text { p-value }\end{array}$ & \multicolumn{1}{|c|}{ SAD } & \multicolumn{1}{c|}{ TIM } \\
\hline \multirow{2}{*}{ TIM } & -2.314003 & \\
\hline VID & $0.0620^{*}$ & 2.638141 \\
& 0.426171 & $0.0250^{*}$ \\
\hline
\end{tabular}

The findings in this study may bring insights to practical aspects, mainly for higher education institutions and/or instructors who seek to develop online courses. Since earlier access brings better achievement, and the choice of the media type is influencing the achievement, instructors are suggested to use video-based learning media upon preparing an online course. However, since video-based media requires more network bandwidth, the instructor must take into account the available and affordable resources of the students.

\section{Conclusion}

The study on learning media is an important matter in education as thoroughly discussed by literature. In the age of Information Technology, the advent of various methods of IT-assisted learning bring forth more options and types of media that can be used. In this study, we evaluated three types of learning media and the correlation with student access behaviors (the first time accessed made and the access frequency), and students' achievement. We found that these parameters are positively correlated, except for the media and the access behaviors. Regarding access frequency and the early access (the first time a student accessed a certain media), as expected, with more frequent access and the sooner the media accessed, the student tends to have better achievement on the evaluation.

In terms of the influence of certain media types on students' achievement, an important matter that we found is the learning media with the appearance of the lecturer yields better achievement, followed by the recorded slide show with audio narration. Learning media that only consists of text and images yields the lowest achievement. This finding is aligned with the finding of a previous study where visual communication has a stronger influence (Appiah 2006; Sherman et al. 2013). Therefore, in the future, this factor should have a major intention when an educator designing a blended learning implementation.

\section{References}

Abuloum, A. M., Farah, A., Kaskaloglu, E., and Yaakub, A. 2019. "College Students' Usage of and Preferences for Print and Electronic Textbooks," International Journal of Emerging Technologies 
in Learning (IJET) (14:07), [Kassel Univ. Press?], pp. 80-97. (https://doi.org/10.3991/ijet.v14i07.9871).

Aini, Q., Budiarto, M., Putra, P. O. H., and Rahardja, U. 2020. "Exploring E-Learning Challenges During the Global COVID-19 Pandemic: A Review," Jurnal Sistem Informasi (16:2), Faculty of Computer Science, Universitas Indonesia, pp. 57-65. (https://doi.org/10.21609/jsi.v16i2.1011).

Aparicio, M., Bacao, F., and Oliveira, T. 2016. “An E-Learning Theoretical Framework," Journal of Educational Technology Systems (19:1), pp. 292-307. (http://www.jstor.org/stable/jeductechsoci.19.1.292).

Appiah, O. 2006. "Rich Media, Poor Media: The Impact of Audio/Video vs. Text/Picture Testimonial Ads on Browsers'Evaluations of Commercial Web Sites and Online Products," Journal of Current Issues \& Research in Advertising (28:1), Taylor \& Francis Group, (https://doi.org/10.1080/10641734.2006.10505192).

Dougiamas, M., and Taylor, P. 2003. "Moodle: Using Learning Communities to Create an Open Source Course Management System," in Proceedings of EdMedia + Innovate Learning 2003, D. Lassner and C. McNaught (eds.), Honolulu, Hawaii, USA: Association for the Advancement of Computing in Education (AACE), pp. 171-178.

Fox, J. 2019. Polycor: Polychoric and Polyserial Correlations. (https://cran.rproject.org/package=polycor).

Gayatri, T., Soegiyanto, H., and Rintayati, P. 2018. "Development of Contextual Teaching LearningBased Audio Visual Adobe Flash Media to Improve Critical Thinking Ability of Geography Learning at Senior High School," IOP Conference Series: Earth and Envi (https://doi.org/10.1088/1755-1315/145/1/012004).

Gozali, C. T., Paturusi, S. D. E., and Sambul, A. M. 2018. "Studi Preferensi Mahasiswa Terhadap Jenis Media Pembelajaran Daring," Jurnal Teknik Informatika (13:4), Program Studi Teknik Informatika Universitas Sam Ratulangi, p. 39-46. (https://ejournal.unsrat.ac.id/index.php/informatika/article/view/24115).

Gutmann, J., Kühbeck, F., Berberat, P. O., Fischer, M. R., Engelhardt, S., and Sarikas, A. 2015. "Use of Learning Media by Undergraduate Medical Students in Pharmacology: A Prospective Cohort Study," PLOS ONE (10:4), (K. E. Vrana, ed.), p. e0122624. (https://doi.org/10.1371/journal.pone.0122624).

Hadibin, M. M., Purnama, B. E., and Nugroho, G. K. 2013. "Pembangunan Media Pembelajaran Teknik Komputer Jaringan Kelas X Semster Ganjil Pada Sekolah Menengah Kejuruan Taruna Bangsa Pati Berbasis Multimedia Interaktif," IJNS - Indonesian Journal on Networking and Security (4:3), pp. 1-6. (https://doi.org/10.1123/IJNS.V4I3.295).

Hart, C. M. D., Berger, D., Jacob, B., Loeb, S., and Hill, M. 2019. "Online Learning, Offline Outcomes: Online Course Taking and High School Student Performance," AERA Open (5:1), SAGE Publications, p. 233285841983285. (https://doi.org/10.1177/2332858419832852).

Hubackova, S., and Semradova, I. 2016. "Evaluation of Blended Learning," Procedia - Social and Behavioral Sciences (217), Elsevier, pp. 551-557. (https://doi.org/10.1016/j.sbspro.2016.02.044).

Kosasih, A., and Angkowo, R. 2007. Optimalisasi Media Pembelajaran, Jakarta: Grasindo.

Lister, M., Dovey, J., Giddings, S., Grant, I., and Kelly, K. 2009. New Media: A Critical Introduction, Second Edition, (2 ${ }^{\text {nd }}$ ed.), Oxford: Routledge.

Moore, J. L., Dickson-Deane, C., and Galyen, K. 2011. "E-Learning, Online Learning, and Distance Learning Environments: Are They the Same?," The Internet and Higher Education (14:2), pp. 129-135. (https://doi.org/10.1016/j.iheduc.2010.10.001).

Nurseto, T. 2012. "Membuat Media Pembelajaran Yang Menarik," Jurnal Ekonomi Dan Pendidikan (8:1). (https://doi.org/10.21831/jep.v8i1.706). 
Okaz, A. A. 2015. "Integrating Blended Learning in Higher Education," Procedia - Social and Behavioral Sciences (186), Elsevier, pp. 600-603. (https://doi.org/10.1016/j.sbspro.2015.04.086).

Paturusi, S. D. E., Chisaki, Y., and Usagawa, T. 2012. "Development and Evaluation of the Blended Learning Courses at Sam Ratulangi University in Indonesia," International Journal of EEducation, e-Business, e-Management and e-Learning (2:3), pp. 242-246. (https://doi.org/10.7763/IJEEEE.2012.V2.118).

Paturusi, S. D. E., Usagawa, T., and Lumenta, A. S. M. 2016. “A Study of Students' Satisfaction toward Blended Learning Implementation in Higher Education Institution in Indonesia," in 2016 International Conference on Information \& Communication Technology and Systems (ICTS), IEEE, pp. 220-225. (https://doi.org/10.1109/ICTS.2016.7910302).

Putri, D. D. 2018. "Pengembangan Learning Management System Menggunakan Framework CodeIgniter Dan AngularJs Di PT. XYZ,” Jurnal Sistem Informasi (14:1), Faculty of Computer Science, Universitas Indonesia, pp. 17-25. (https://doi.org/10.21609/jsi.v14i1.540).

Putri, M. P., and Solfema, S. 2019. "The Relationship Between Variations in the Use of Learning Media and the Learning Activity of Citizens Learning," Indonesian Journal of Contemporary Education (1:1), pp. 36-40. (http://journal.iiesindependent.org/index.php/ijce/article/view/25/20).

R Core Team. 2020. R: A Language and Environment for Statistical Computing, Vienna, Austria. (https://www.r-project.org/).

Sengkey, D. F., Kambey, F. D., Lengkong, S. P., Joshua, S. R., and Kainde, H. V. F. 2020. "Pemanfaatan Platform Pemrograman Daring Dalam Pembelajaran Probabilitas Dan Statistika Di Masa Pandemi CoVID-19," Jurnal Informatika (15:4), pp. 217-224.

Sengkey, D. F., Paturusi, S. D. E., and Sambul, A. M. 2019. "Identifying Students' Pre-Classroom Behaviors in a Flipped Learning Environment," Journal of Sustainable Engineering: Proceedings Series (1:2), pp. 143-149. (https://doi.org/10.35793/joseps.v1i2.19).

Sengkey, D. F., Paturusi, S. D. E., and Sambul, A. M. 2020. "Perbandingan Akses Mahasiswa Terhadap Media Pembelajaran Daring Dalam Penerapan Flipped Classroom," Jurnal Teknik Elektro Dan Komputer (9:1), pp. 31-38. (https://doi.org/10.35793/JTEK.9.1.2020.28634).

Sengkey, D. F., Paturusi, S. D. E., Sambul, A. M., and Gozali, C. T. 2019. "A Survey on Students' Interests toward On-Line Learning Media Choices (A Case Study from the Operations Research Course in the Department of Electrical Engineering, UNSRAT)," International Journal for Educational and Vocational Studies (1:2), pp. 146-152. (https://doi.org/10.29103/ijevs.v1i2.1527).

Sengkey, D. F., Sambul, A. M., and Paturusi, S. D. E. 2019. "Penilaian Mahasiswa Terhadap Jenis Media Pembelajaran Dalam Penerapan Flipped Classroom," Jurnal Teknik Elektro Dan Komputer (8:2), pp. 103-110. (https://doi.org/10.35793/JTEK.8.2.2019.25029).

Setyaningrum, W. 2016. "Teachers' Perception Towards ICT in Mathematics Class : A Case Study in Yogyakarta Secondary Schools," in Proceeding of 3rd International Conference on Research, Implementation and Education of Mathematics and Science, Yogyakarta, Indonesia, pp. ME263ME268. (http://seminar.uny.ac.id/icriems/sites/seminar.uny.ac.id.icriems/files/prosiding/ME39.pdf).

Setyaningrum, W. 2018. "Blended Learning: Does It Help Students in Understanding Mathematical Concepts?," Jurnal Riset Pendidikan Matematika (5:2), pp. 244-253. (https://doi.org/10.21831/JRPM.V5I2.21428).

Sherman, L. E., Michikyan, M., and Greenfield, P. M. 2013. "The Effects of Text, Audio, Video, and In-Person Communication on Bonding between Friends," Cyberpsychology: Journal of Psychosocial Research on Cyberspace (7:2). (https://doi.org/10.5817/CP2013-2-3).

Suarta, I. M., and Suwintana, I. K. 2015. "The Influence of E-Learning Characteristics and Basic ICT Competencies to Actual Usage of e-Learning: A Path Diagram Model," Jurnal Sistem Informasi 
(11:2), Faculty of Computer Science, Universitas Indonesia, pp. 59-67. (https://doi.org/10.21609/jsi.v11i2.433).

Susilana, R., and Riyana, C. 2009. Media Pembelajaran: Hakikat,Pengembangan,Pemanfaatan,Dan Penilaian, Bandung: CV.Wacana Prima.

Usagawa, T., and Ogata, K. 2015. "Potential of E-Learning for Enhancing Graduate and Undergraduate Education," IPTEK Journal of Proceeding Series (1), pp. KS2-3-KS2-6. (http://iptek.its.ac.id/index.php/jps/article/view/1115).

Wang, C. H., Shannon, D. M., and Ross, M. E. 2013. "Students' Characteristics, Self-Regulated Learning, Technology Self-Efficacy, and Course Outcomes in Online Learning," Distance Education (34:3), pp. 302-323. (https://doi.org/10.1080/01587919.2013.835779).

Yeşil Dağl1, Ü. 2019. "Effect of Increased Instructional Time on Student Achievement," Educational Review (71:4), Routledge, pp. 501-517. (https://doi.org/10.1080/00131911.2018.1441808).

How to cite:

Sengkey, D. F., Paturusi, S. D. E., and Sambul, A. W. 2021. "Correlations between Online Learning Media Types, First Access Time, Access Frequency, and Students' Achievement in a Flipped Classroom Implementation," Jurnal Sistem Informasi (Journal of Information System) (17:1), pp. 44-57. 